\title{
The Problem of Having Blurred Cultural Identity in Andrea Levy's Small Island and Bahaa Taher's Sunset Oasis: A Comparative Study
}

\author{
Dr. Rasha Farouk Mahmoud Hamza \\ Lecturer of English Literature, English Department, Faculty of Al-Alsun \\ (Languages), Luxor University, Egypt.
}

\begin{abstract}
Post-colonialism is one of the most important theories of the Twentieth Century. Generally, it indicates a series of theories and critical approaches that try to defy the inheritance of the colonial era. Additionally, it also refers to the literary writings of the colonized; whether during or after colonialism. This paper tries to investigate the theme of cultural identity as one of the most important themes in postcolonial theory and criticism. This term refers to the ways of preserving the culture of a group of people against the destruction of identity, inflicted by the colonizer. This can only be implemented by identifying with the individual's native cultural identity. The current paper is an analytic study of the theme of cultural identity in the novel by the Jamaican author, Andrea Levy's Small Island (2006), and the Egyptian writer, Bahaa Taher's Sunset Oasis (2008). This paper applies Homi K Bhabha and Gayatri Spivak's concepts of cultural identity in a postcolonial/imperialist context. This is with special reference to the previously mentioned novels.
\end{abstract}

Key Words:

Post-colonialism, Homi K. Bhabha, Gayatri Spivak, Andrea Levy, Bahaa Taher. 
مجلة وادي النيل للاراسات والبحوث الإنسانية والاجتماعية والتربوية (مجلة علمية محكمة)

(ISSN : 2536 - 9555)

اشكالية امتلاك هوية ثقافية مشوشة كما يتضح فى رواية جزيرة صغيرة ل "أندريا

ليفي" ورواية واحة الغروب ل "بهاء طاهر" : دراسة مقارنة

د. رشا فاروق محمود حمزة

مدرس الأدب الإنجليزى - قسم اللغة الإنجليزية-كلية الألسن

جامعة الأقصر - مصر - معن

الملخص:

تعتبر نظرية ما بعد الكولونيالية واحدة من أهم نظريات القرن العشرين. فهى على

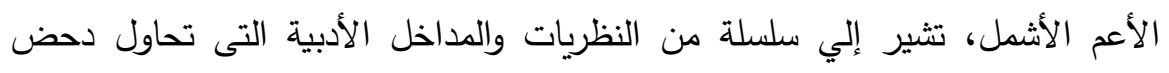

موروث الحقبة الاستعمارية.و بالإضافة إلي ذلك، فإن تلك النظرية تثير النيل الني الكتابات

الأدبية للشعوب المستعمرة في أثناء الحقبة الاستعمارية أو ما بعدها، علي حد السواء.

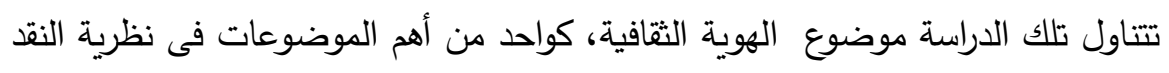

ما بعد الكولونالى. ويشير ذلك المصلح إلي محاولات الحفاظ علي ثقافة مجموعة من

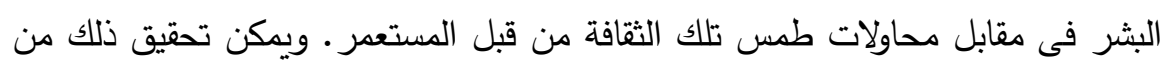

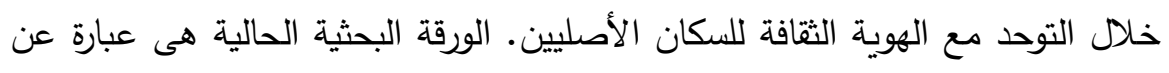
دراسة تحليلية لموضوع الهوية الثقافية فى رواية جزيرة صغيرة (T (ب) للكاتبة الجامايكية "أندريا ليفى"، ورواية الكاتب المصري "بهاء طاهر" واحة الغروب" (1 . . ب). وتقوم هذة الورقة البحثية بتطبيق مفهوم الهوية الثقافية فى النصوص المكتوبة فى حقبة ما بعد الكولونيالية/ الاستعمارية، وذلك طبقا لمفهوم كلا من هومى بابا وجايترى لون لونه سبيفاك. ويتم تطبيق هذة المفاهيم علي الروايات سالفة الذكر.

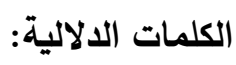

نظرية ما بعد الكولونيالية، هومى بابا، جايترى سبيفاك، أندريا ليفى ، بهاء طاهر . 
The Problem of Having Blurred Cultural Identity in Andrea Levy's Small Island and Bahaa Taher's Sunset Oasis: A Comparative Study

Dr. Rasha Farouk Mahmoud Hamza

مجلة وادي النيل للار اسات و البحوث الإنسانية والاجتماعية والتربوية (مجلة علمية محكمة)

\section{The Problem of Having Blurred Cultural Identity in Andrea Levy's Small Island and Bahaa Taher's Sunset Oasis: A Comparative Study Dr. Rasha Farouk Mahmoud Hamza}

Post colonialism is a very popular term in the realm of literary criticism and literary theory. Arif Dirik in The Postcolonial Aura: Third World Criticism in the Age of Global Capitalism mentions three different employment of the term. The first usage of the term is as a " literary description of conditions in the formerly colonial societies" (332); secondly, it is used as a " description of a global condition after the period of colonialism"(332); thirdly, it is used as a "discourse in the abovenamed conditions that is informed by the epistemological and psychic orientations that are products of these conditions"(332). Thus, post colonialism means a cultural study of the impact of colonialism on the literature and arts of the ex-colonies. However, the term postcolonial is mainly used in the literature produced by the former colonies of Europe. This term has recently replaced terms like "Third World Literature", "Commonwealth Literature" and "New Literature in English"(332).

Thus, postcolonial literature and theory investigate what happens when two cultures clash, and one of them considers itself superior to the other. Bill Ashcroft, in The Empire Writes Back employs the term post-colonial to highlight the fact that any culture can be affected by colonialism, from the first day of occupation, till the current day. Post-colonialism is considered the phase that puts an end to colonialism, by granting the natives the power to rule themselves. Moreover, it gives the natives political and cultural freedom to take their place and gain their full independence by overcoming the legacy of political and cultural colonialism. Consequently, the term cultural identity is one of the most important concepts of postcolonial theory and criticism. Postcolonial literature tries to answer the question of how can the 
مجلة وادي النيل للاراسات والبحوث الإنسانية والاجتماعية والتربوية (مجلة علمية محكمة)

(ISSN : 2536 - 9555)

colonized (the self), resist the colonizer (the other). Many authors of the postcolonial literature believe that focusing on the cultural identity of the colonized is a way of fighting the colonizer. However, this imposes very important questions, such as: is there a pure identity? Is the culture of the colonized remained pure and untouched by the colonizer's culture? If the culture of the colonized became a mixture of the colonizer and the colonized culture, would that be a sign of resistance or surrendering? Actually, Homi K. Bhabha believes that this is a sign of resistance. While, on the other hand, Spivak believes that a hybrid identity is a sign of surrendering to the colonizer's own identity.

Bhabha's The Location of Culture is considered to be one of the best books to deal with the various aspects of the postcolonial theory. In this book, Bhabha introduces many concepts, which are fundamental to postcolonial criticism. All these concepts are the colonized people's way of resisting the power of the colonizer. Additionally, in this book, he tries to reshape our understanding of cross-cultural relations. Bhabha developed the term of cultural hybridity to stress the idea that: many postcolonial writers have a sense of belonging to both the culture of the colonizer and that of the colonized.

Hybridity is one of the most important concepts that Bhabha discusses in his book. Ashcroft argues in his book, The Empire Writes Back, that "Hybridity is the creation of new transcultural forms within the contact zone, produced by colonization"(11). Hybridization takes many forms including cultural, political, and linguistic forms. However, he believes that to perform the strategy of hybridity is not to erase the colonial authority, but to demonstrate the power with something different from its original presence. This strategy helps the colonizers rationalize their discrimination towards the identities and power of the colonized. By describing the colonized with such identities, the colonizer can still be in the position that enables him to escape from being an oppressor. Bhabha believes that there is no nation or culture which is totally pure. Cultural identity is the product of an amalgamation of the culture of the colonized and that of the colonizer. 
مجلة وادي النيل للاراسات والبحوث الإنسانية والاجتماعية والتربوية (مجلة علمية محكمة)

Mimicry is another important concept in the postcolonial theory. As mentioned by Ashcroft, in his famous book, Postcolonial Studies, Key Concepts:

When colonial discourse encourages the colonial subject to

"mimic" the colonizer, by adopting the institutions

and

principles. Nevertheless, the product is definitely not a reflection of them .consequently the production is an unauthenticated image of the colonizer

That can be quite threatening. (139)

In The Location of Culture, Bhabha believes that:

Mimicry reveals something in so far as it is distinctive from what might be called in itself that is behind. The effect of mimicry is camouflage...It is a question of harmonizing with the background, of becoming mottled like the technique of camouflage practiced in human warfare. (121)

Mimicry, in Bhabha's terms, is the colonial strategy to create the people "to be Anglicized is emphatically not to be English"(132). Bhabha's concept of mimicry means repetition and not representation. However, it is a repetition with a difference. Yet, this repetition is threatening to the basis of power and discrimination as "there is a distinctive quality of English civilization"(132). In short, Bhabha believes that the colonizer presents the colonized as savages and barbaric. Nevertheless, by being able to imitate and mimic the colonizer's culture, the colonized is challenging the stereotypical image of the colonizer. Thus, it is a kind of resistance, that the colonized can prove his/her ability to mimic the colonizer. Consequently, the colonized natives have the power to fight back with the colonizer using the colonizer's own weapons. It is not only a tool for self-deference, 


\section{مجلة وادي النيل للاراسات و البحوث الإنسانية والاجتماعية والتربوية (مجلة علمية محكمة)}

(ISSN : 2536 - 9555)

but also for some natives, the only way to cope with the oppression.

A great example of Bhabha's concept of mimicry is Andrea Levy's novel Small Island. Andrea Levy is a British writer of Jamaican descent. Her parents are Jamaican immigrants, who came to England during post-wartime from the Caribbean Islands. These immigrations resulted in what was known as the "Wind rush Generation". During her adulthood years, Levy started to write about her childhood memories, and what it was like to grow up like a black child in a predominantly white- country like Great Britain. Levy wrote five novels and two collections of short stories. They are: Every light in the House Burning (1994), Never Far from Nowhere (1996), Fruit of the Lemon (1999), Small Island (2004), and The Long Song (2010). At the age of sixty-two, Andrea Levy died in England in February 2019.

Small Island tells the story of the Caribbean migration that took place after the end of World War II. This happens through the eyes of its four major characters. The first couple is Hortense and her husband Gilbert. They both immigrated to England, the land of their dreams, in 1948. The other couple in the novel is the British couple: Queenie and Bernard. Hortense and Gilbert take residence in Queenie and Bernard's London house. The novel displays the effect of colonialism on ordinary people from two entirely different cultures. The colonized, Gilbert and Hortense, who face discrimination, refusal, and racism from the English society, and on the other hand, the colonizer, Queenie who accepts diversity, becomes a friend of Hortense and has an affair with a colored man. This is contrary to her husband's feelings of superiority against black people, and his refusal of their existence in his community.

Actually, Bhabha's concept of hybridity and mimicry can be easily applied to the character of Hortense. Hortense is the protagonist of the novel. She is a young girl from the Island of Jamaica. She is an illegitimate daughter of a white rich man and a white Jamaican maid. Her mother believes that because Hortense has light skin, she has a great chance to have a good future. This makes her decide to give her daughter to the Roberts, the cousins 
of Hortense's father. The Roberts will teach her proper English manners and respectability. Hortense is raised in a colonial school, where she is taught to highly appreciate British manners and believes, to be a British citizen. Her only dream in life is to immigrate to England where she can have a job as a teacher and finally have a decent life. When WWII breaks, Hortense fears for her life from Hitler (she is a Jew). She believes that Britain will save Jamaica from Hitler and his troops. She is convinced that: "Britons will never, never, never, shall be slaves"(26). As a matter of fact, Hortense's attitude is rather ironic. She visualizes Hitler as the enemy and Britain which occupies her country, as the one who will save the Jamaicans from occupation.

As time passes by, Hortense's dream and desire to go to England grows bigger and bigger. She imagines living in England, cooking English food, and having the afternoon tea. She fantasizes about going shopping and the storekeeper will greet her politely in perfect English. She is ready to do whatever it takes to fulfill her dream. She betrays her friend, Celia by convincing her fiancé Gilbert Joseph to marry her, and she will pay for his ticket to England.

In her promised land, England, Hortense confronts some cultural shocks. The first one is when she meets an English woman who asks her about another Jamaican girl. The English woman is surprised that Hortense does not know the girl. This English woman believes that all Jamaicans know each other. This incident makes her realizes that the people whom she spent her life studying their manners and history, they know nothing about Jamaica and Jamaican people; they only regard them as inferiors.

Hortense's second shock in England is when she sees the English women, including Queenie, wearing simple clothes, while she wears fine clothes. Actually, Hortense received a better education than Queenie. Hortense describes Queenie saying:

For these dismal garments, which I had taken to be her dressing gown, was her good outside coat [...] 


\section{مجلة وادي النيل للاراسات والبحوث الإسانية والاجتماعية والتربوية (مجلة علمية محكمة)}

(ISSN : 2536 - 9555)

She looks on me distasteful, up and down. I was dressed as a woman such as I should be when visiting the shops in England. My coat was clean, my gloves freshly washed, and a hat upon my head. But Mrs. Bligh stares at me as if something was wrong with my apparel, before telling me once more, "I'm not worried about what busy bodies. I don't mind being seen in the street with you". (239)

While Queenie treats Hortense as a savage who does not know what a store is, Hortense is disgusted by the way the British storekeeper holds the bread with his dirty hands. Furthermore, another incident which proves that no matter what effort is exerted by the hybrid to mimic the colonizer, the colonized will remain always inferior. The colonized can try to be "Angelized", but s/he shall never be worthy of being English. Hortense works so hard to fulfill her dream and be a teacher, but she receives a rude and bad treatment by the staff of the school; she never fits their profile:

How long is the training in England? I asked her "Goodbye", she said, pointing a finger at the door. Must I go back to college?

Really, Miss, I have just explained everything to you, you speak English? Have you not understood me? It's quite simple. There is no point in you asking me anything else. Now, please, I have a lot to do. Thank you.

And she smiled at me, again! What fancy feigning

As I stood she rolled her eyes with the other women in the room. (455)

Actually, the above situations are reflections of Bhabha's concept of mimicry. Mimicry occurs when members of a colonized society imitate the language, dress, politics, or cultural attitude of their colonizers. According to Bhabha, the colonized wants to mimic the 
colonizer, who possesses power, in the hope to possess the same power one day. Bhabha, also, believes that if the colonized are obsessed with the colonizers' manners and tries to mimic them, this will reveal the artificiality of these manners. This will also expose how shallow those manners are. This is clear when Hortense fails to have a job as a teacher in an English school. This makes her realize that she does not belong to this society and that this society does not accept her as one of its members. Then, and only then, Hortense starts to care for her husband, believing that they belong to each other.

Furthermore, when Queenie gives birth to her hybrid child, she asks Hortense to help her. Hortense acceptance to help Queenie, and not being bothered about her wedding dress getting stained with blood, shows that Hortense is no longer the woman who cares about the British manners. She agrees on adopting Queenie's baby, believing that he should be raised by people who look like him.

Additionally, the character of Gilbert Joseph is another example of an identity crisis in hybrid personalities. Mr. Joseph is a young Jamaican man who leaves for England and joins the English army during the war. Like Hortense, he believes that England is the Promised Land in which he will find a decent job. He does not consider England to be a colonial country, but on the contrary, he believes that England is his motherland. So when World War II starts, he decides to join the army and gets deployed in England. There, Gilbert finds out the truth that England is nothing but a colonized country. England is a colonizer that does not care about the people of its colonies. He is totally shocked to see the amount of discrimination and racism against colored people. In the army, he is forbidden from assuming any remarkable position that will make him equal to white people.

After spending years in England, he longs for Jamaica and decides to come back. But, living in England for many years, makes him feel that Jamaica is a small island, with limited economical and professional opportunities. He says: "at that 
مجلة وادي النيل للاراسات والبحوث الإنسانية والاجتماعية والتربوية (مجلة علمية محكمة)

(ISSN : 2536 - 9555)

moment, standing tall on Kingston Harbor, I was shocked by the awful realization that man; we Jamaicans are all small islanders too!"(163). Gilbert has a feeling of displacement. Gilbert believes that he neither belongs to Jamaica, that shall never provide him with a good life, nor does he belong to England, which is full of prejudice and racism.

Actually, this split in Gilbert's identity reflects Bhabha's concept of hybridity. He is a mixture of two cultures, without belonging to a specific one of them. Gilbert wants to belong to England, as a British citizen, at the same time, he is aware of the truth that the English society treats him as an inferior.

Eventually, and as time passes, Gilbert learns to realize that not everything the English does is good. "Not everything, I tell her, not everything the English do is good."(P.271). Gilbert tells Hortense that the English people eat food out of the newspaper, in which it is wrapped in. He tells her that to teach her not to depend on the British to fulfill the civilized manners. He tries to support Hortense when she fails to get a teaching job. He tells her that immigrant life is hard and that he remembers a white fellow in the army, who knows nothing about British History, but he got a job as a teacher. Gilbert earns a new habit of greeting and waving to any Jamaican he sees in England, even though, he does not know him. Hortense objects to this attitude, but he explains to her that doing so makes him appreciates his own race, and this, in itself, makes him comfortable to see another black man. At the end of the story, Gilbert realizes that he is not a British citizen, who does not belong to England. Now, he believes that he and his wife belong to each other and that both of them belong to the immigrants who look like them.

Another important concept in the post-colonial theory is the concept of the subaltern. The term subaltern comes from the Latin origin "sub", which means below, and "alternus" which means "all others". So, subaltern refers to a second-rate position. The term was originally coined by the Marxist thinker Antonio Gramsci in his article, "Notes on Italian History" from his book: Prison 
Notebooks (1925). By this term, he refers to the silenced proletariat, the poor workers who have no voice.

Later on, the term was used in critical writings and theory. The term was also used to the second rate people, who are oppressed and muted by the elite class. Unlike Antonio Gramsci, the Indian critic, Gayatri Spivak, does not believe in the Marxist interpretation of subalternity. In her famous essay, "Can the Subaltern Speak?" Spivak argues that the colonized has been silenced and oppressed for so many years by the colonizer. Additionally, she believes that when the intellectuals speak about the oppressed subaltern group, they are not really giving them a voice. She states: "For the true subaltern group, whose identity is its difference, there is no un presentable subaltern subject that can know and speak itself; the intellectual's solutions are not abstaining from representations" (Subaltern, 285). Spivak believes that women in postcolonial texts are double oppressed. They are oppressed by their patriarchal societies, and by the process of colonization itself. Consequently, this resulted in them having a blurred identity, and trying to find their real selves.

As a matter of fact, the idea of an identity crisis, and having a blurred identity of the subalterns, is a dominant theme in the novel Sunset Oasis by Bahaa Taher. Taher was born in 1935 in Giza, Egypt, to Upper Egyptian parents from the village of Karnak, Luxor. He has published seventeen books including: six novels, five short story collections, and six non-fiction works. He also translated many books and literary works from English and French into Arabic. In 2008, his novel, Sunset Oasis, written in 2006, won the prestigious Arabic Booker Prize in literature.

Sunset Oasis is set in the late nineteenth century, at a time marked by the British colonialism of Egypt, and the failure of the Orabi's Revolution. The novel tells the story of the police officer, Mahmoud Abdelzaher, who participated in the events of the Revolution. After the drastic failure of the Revolution, Mahmoud was interrogated by the British forces. He was exiled to the Sunset Oasis, as a punishment for him. There, he becomes the district 


\section{مجلة وادي النيل للاراسات و البحوث الإنسانية والاجتماعية والتربوية (مجلة علمية محكمة)}

(ISSN : 2536 - 9555)

commissioner. His main responsibility is to collect taxes from the poor Berber tribes, on behalf of the British Occupation. He goes on a dangerous journey to the oasis, accompanied by his Irish wife, Catherine. Catherine is obsessed with Ancient Egyptian history and monuments. Together they set off towards the 500 kilometer-awayfrom-Cairo oasis.

Actually, Taher in this novel presents characters in the middle of the cultural identity crisis. Maleeka, Catherine, and Mahmoud are examples of the dilemma of the subaltern. They are all oppressed in a society that treats them as second-rate citizens. However, they never succumb to this type of oppression; imposed on them by" the other". They keep on searching for their own cultural identity: "their selves", till the end of the novel.

Maleeka is a minor character in the novel, yet she is one of the most important example s of subalternity in the novel. She is a young innocent girl from the Siwa Oasis. She is one of the most important girls in the oasis, and the favorite niece of Shiekh Yahiya, the head of the tribe. The mother of Maleeka forces her to marry an old man from the other tribe "The Orientals", as a way to reinforce peace between the two tribes. The tragedy of Maleeka's character starts when she becomes an embodiment of the ghoulwoman or Ghoula. According to the Siwan's traditions and practice, a Ghoula is a widow who has to stay at home for four months and ten days, "so that she could become cleansed of the spirit has possessed her and brought death to her husband." (Sunset Oasis, 111). During this period the woman, who is believed to be inhabited by the angel of death, "was not allowed to change her mourning dress, no matter how dirty it got. She could not bathe and she could not put on make-up."(116).

However, young Maleeka does not accept her destiny and rebels. Maleeka is a rebellious character that does not succumb to the fact that she is considered a subaltern. First, she refuses to accept the old man as a husband and runs away from her mother's home. She does not succumb to the Ghoula myth, and disguises herself in men's clothes, to leave the house and play with the children. She even visits Catherine at home and offers her 
friendship. Later on in the novel, Maleeka dies as a result of her rebellion. However, the character of Maleeka becomes the voice of struggle and resistance. She fights the wrong norms of her community and refuses to succumb to such marginalization. Maleeka was what Mahmoud tries to be. Her death becomes a trigger to him to find his own identity, and encourages him to resist colonialism, even if this will cost him his life.

Another important character in the novel, that represents the identity crisis, is the character of Catherine. Catherine is a young Irish woman. Back in Ireland, Catherine was married to an Irish man. After his death, Catherine decides to visit Egypt. Catherine has inherited her love and obsession with antiques and Ancient Egypt from her late father. So, she decides to come to Egypt to visit the temples, and this is where she meets Mahmoud and they both get married.

Catherine has two identities; she is the Irish woman who hates the British for colonizing her country. Nevertheless, she is a British citizen, who lives in Egypt as superior to the Egyptians. She has a hybrid identity. Catherine is the colonizer and the colonized at the same time. When she got married to Mahmoud, she submits to him. She accepts to live with him while he is cheating on her. She even gives up her own language and talks to him in Arabic. In Ireland, Catherine is colonized by the British, and in the Oasis, she is the colonizer. She treats the native inhabitants of the oasis as inferior to her. Catherine assumes that she knows everything about the oasis from the books that she brought from Ireland. These books represent the well-known stereotypical conceptions about the East.

Catherine believes that she is the only one who can discover the secrets of the oasis. She is obsessed with Alexander the Great, not caring that Alexander the Great himself was a colonizer. Catherine hates the existence of the British on her own land, while she justifies and praises another colonizer. Moreover, she considers the inhabitants of the oasis as savages. She believes that they have destroyed the temple and have always underestimated its value. 


\section{مجلة وادي النيل للاراسات و البحوث الإنسانية والاجتماعية والتربوية (مجلة علمية محكمة)}

(ISSN : 2536 - 9555)

The oasis reinforces her feelings of alienation; no one there wants to talk to her. They consider her to be the colonizer, whom they hate and refuse her existence, she says: "I have to break this isolation before I turn into melancholy. If I had not had the books and reading the idea of the search, I would have become completely lunatic during these last weeks" (Sunset Oasis, 196). Catherine fails to interpret Maleeka's offer of friendship and considers it a hostile act of an inferior and a felony of trespassing.

During her stay at the oasis, Catherine continues to play the role of the colonizer. She does not appreciate Sheikh Yahiya's kind act of forgiving her after Maleeka's death, nor his effort to help her treat her sister, Fiona. She describes his treatment as primitive, just like him and the rest of his tribe. In the end, Catherine decides to leave everything behind her: Mahmoud, the Oasis, and Egypt. All these things are reinforcing her sense of alienation and loss of identity. She declares: "In any case, I shall leave... This is a final decision. I shall have done with everything concerning Mahmoud, Maleeka, this Oasis, Egypt and its people. All this shall be behind me soon" (Sunset Oasis, 262). Catherine is a perfect example of having a blurred identity. She is stuck in the middle of two cultures and plays two roles. She is colonized by the British, while she is the colonizer in the Oasis.

Mahmoud Abdelzaher is the protagonist of the novel. He is a police officer who lives a luxurious life. His father was a rich merchant, and he was raised as a Western man by foreign governesses. However, Mahmoud believes in and supports people like Gamal Eldeen Al-Afghany. He also secretly participates in Orabi's Revolution against the British colonialism. He visualizes himself as a hero, who protects the people of Alexandria from the British bombardment. At the same time, he is the officer who works under the British administration. $\mathrm{He}$ is the one who condemns Orabi's Revolution in front of the British. Mahmoud even calls Orabi traiter, to save his job. When Mahmoud meets Catherine for the first time, he does not speak to her gently till he knows that she is Irish, and hates the British occupation. Nevertheless, he cannot deny the fact that she is still a British 
The Problem of Having Blurred Cultural Identity in Andrea Levy's Small Island and Bahaa Taher's Sunset Oasis: A Comparative Study

Dr. Rasha Farouk Mahmoud Hamza

مجلة وادي النيل للاراسات والبحوث الإنسانية والاجتماعية والتربوية (مجلة علمية محكمة)

citizen. Marrying Catherine makes him think that he has power over the colonizer, and by this, he conquers the British. He thinks that marrying her will lead him to find peace, but he was wrong, he says to himself:

I ask whether the parts of the young man, with his divided spirit, have come together, or whether the days have flung them further apart. When I married Catherine, after much hesitation, I dreamt that my unruly self might finally calm down... why did that peacefulness never come? Why does it remain elusive and out of reach? (Sunset Oasis, 120)

Mahmoud suffers from a split in his identity. He is in the middle of two cultures. As he arrives at the Oasis, he feels that he hates the people there. They see him as a representative of the colonizer, who forces them to pay the taxes. In rethinking the whole situation, he realizes the people of the Oasis have the right to hate him, he says:

I came to this Oasis hating it and its people, and I have come to hate them even more because of their hostility towards me, Catherine, and even the troops. Nevertheless, the more I think about what we have done to them since we came here as rulers, the more I find their behavior perfectly natural. We did not come to them as brothers but as conquerors. We did not treat them as fellow citizens but as though they were a colonized people who had to pay their taxes to the conquerors, whether they like it or not. Why then should we get angry at what the British were doing to us...? We practice the law of might here, just as the British practice it there. (Sunset Oasis, 164) 
مجلة وادي النيل للاراسات والبحوث الإنسانية والاجتماعية والتربوية (مجلة علمية محكمة)

(ISSN : 2536 - 9555)

Eventually, Mahmoud gains some boldness to face himself with facts. He faces himself with his split identity. He realizes that he lives the life of "halves". He is half good, half evil, half brave, half coward, half patriot, half traitor. He is always in the middle of something, and he is tired of his hybrid identity. He refuses and resents this blurred identity. Consequently, this refusal becomes his first step towards resistance.

Mahmoud faces himself with the fact that marrying Catherine adds to his feelings of alienation and hybridity. He visualizes Catherine as a symbol of superiority, hybridity, and racism against the natives. This realization makes his marriage falls apart. Mahmoud believes that both Maleeka and Fiona, Catherine's sister, are good models of what he cannot be. Maleeka refuses to surrender to her society and its customs and traditions. She fights her society's ignorance and beliefs in myth and superstitions. She struggles for her own freedom, though she knows very well that this might cause the loss of her own life. Likewise, Fiona is someone who is sure about her own identity as an Irish woman, who hates the British colonialism and considers Orabi to be a hero. From her own point of view, Orabi is a heroic figure who fights for the independence and sovereignty of his own homeland. On her conversation with Wasfy, a fellow colleague of Mahmoud, Fiona does not hesitate for a second to defend Orabi against Wasfy's accusation of treason. Mahmoud wishes to be able to fight for his freedom even if this costs him losing his job. He longs to be sure about where he belongs, just like Fiona. At the end of the novel, Mahmoud decides to destroy the rest of Alexander the Great's Temple. He wants to destroy the remaining walls using dynamite. He believes that this temple symbolizes the legacy of colonialism. Now he realizes that one should get rid of the past, look forward to the present, and fight colonialism, even if this means costing him his own life. This is the only way to regain his true identity. Mahmoud addresses death at the end of the novel saying: "Thanks for coming too late" (Sunset Oasis, 220). Death liberates Mahmoud from his eternal struggle to find his real identity. 
In short, both Andrea Levy and Bahaa Taher have managed to give a true and faithful portrayal of characters living in the middle of an identity crisis. Small Island and Sunset Oasis present characters suffering from having blurred identities. They feel lost and cannot identify their own identities. This is due to their hybridity, mimicry, or subalternity. Hortense and Gilbert try to fight their own hybridity and their own sense of displacement by mimicking "the other", the colonizer. According to Bhabha, mimicry is a way of resisting the cultural dominance of the colonizer. This type of mimicry (mimicry without a difference) demonstrates the shortcomings of the domineering society of the colonizer.

Likewise, both Mahmoud and Catherine in Sunset Oasis suffer from an identity crisis. Catherine is fluctuating between her two identities. She is the colonized, as being an Irish colonized by the British, and the colonizer who has a British citizenship. Nevertheless, she decides to side with her colonial identity, and treat the native people of the Oasis with superiority. On the contrary to Catherine, Mahmoud, right from the beginning dislikes his hybrid identity; being colonized and representative of the British Colonization in the Oasis. Mahmoud fights colonization and destroys its symbols in the Oasis: The Temple of Alexander The Great. Eventually, this act costs him his own life. Meanwhile, Maleeka is another example of Spivak's model of a subaltern. Nevertheless, she refuses to succumb to her subalternity and revolts against it.

Hybridity, mimicry, and subalternity are all manifestations of the crisis of cultural identity. The characters of Small Island and Sunset Oasis are going through a great struggle to define their own true cultural identities. While some of them prefer to mimic the identity of the colonizer. Others, on the other hand, refuse to surrender and choose to fight subjection, even if this means losing their own lives, in the end. 
مجلة وادي النيل للاراسات والبحوث الإنسانية والاجتماعية والتربوية (مجلة علمية محكمة)

(ISSN : 2536 - 9555)

\section{References}

Akbar, Arifa. "Sunset Oasis: A Vision of Freedom in Egypt's Colonial Wilderness". September, 2009

$<\mathrm{http}$ ://www.independent.co.>

Aspden, Rachel. "Sunset Oasis by Bahaa Taher". The Guardian. November 2009.

$<\mathrm{https} / /$ www.the guardian.com/profit rachel- aspden $>$

Barker, Chris. Cultural Studies: Theory and Practice. London: SAGE, 2005. Print.

Bhabha, Homi. The Location of Culture. London, New York: Rutledge, 1994. Print.

Dirik, Arif. The Postcolonial Aura: Third World Criticism in the Age of Global Capitalism. Chicago: Chicago Up., 1994. Print.

Donnell, Alison. Twentieth- Century Caribbean Literature: Critical Moments in Anglophone Literary History. London and New York: Rutledge, 2006. Print.

Fischer, Susan Alice. "Andrea Levy's London Novels", The Swarming Streets: Twentieth Century Literary Representation of London. Lawrence Philips. ed. Amsterdam: Rodopi, 2004. Print.

James, Cynthia. "You'll Soon Get Used to Our Language": Language, Parody, and West Indian Identity in Andrea Levy's Small Island, Anthurium. Caribbean Studies Journal 5-1 (2007):1-14.

http://scholaryrespitory.miami.edu/anthurium/vol5/iss113

Levy, Andrea. Small Island. London: Headline Publishing Group, 2004. Print.

--- "This is my England", The Guardian, 19 February 2000. http://www.guardian.co.uk/books/2000/feb/19/society [Accessed 10 January 2012].

Mcleod, John. Postcolonial London, Rewriting the Metropolis. Oxford: Rutledge, 2004. Print. 